\title{
Soil pore distribution as affected by cattle trampling under no-till and reduced-till systems
}

\author{
Iglesias, J.O.; J.A. Galantini, H. Krüger and S. Venanzi
}

\begin{abstract}
SUMMARY
Soil pore size affects soil air and water dynamics, and thus influence crop productivity. The aim of this study was to evaluate the impact of reduced-tillage (RT) and no-tillage (NT) systems on soil pore distribution under animal grazing. The soil was sampled at 0-5, 5-10, 10-15 and 15-20 cm depths before and after animal grazing. Bulk density, total porosity and the volume of three pore sizes (macropores, mesopores and micropores) were determined. Differences in total porosity between both tillage systems were statistically significant $(P<0.01)$ in the top $10 \mathrm{~cm}$ layer before grazing. Lower total porosity in NT could be related to the effect of previous years'grazing. In RT, disk operations before planting the oat (Avena sativa) crop increased porosity values in the tilled zone at 0-10 cm and decreased them at depths below $10 \mathrm{~cm}$. Macroporosity accounted for 32 (RT) and 20\% (NT) of the total porosity in the soil surface, and decreased to 17 (RT) and 17\% (NT) in deeper layers. Cattle trampling had a more pronounced effect under RT as compared with NT. Tillage operations increased macroporosity, which had been reduced by cattle trampling. Bulk density and total porosity were adversely affected below $15 \mathrm{~cm}$ depth.
\end{abstract}

Keywords: soil porosity, animal trampling, semiarid regions

Iglesias, J.O.; J.A. Galantini, H. Krüger y S. Venanzi, 2014. Cambio en la distribución de poros de suelos en siembra directa y labranza reducida con pastoreo animal. Agriscientia 31 (2): 93-102

\section{RESUMEN}

Los diferentes tamaños de poros modifican la dinámica del aire y agua edáfica, influyendo sobre la productividad de los cultivos. El objetivo de este estudio fue evaluar el efecto de la labranza reducida (RT) y la siembra directa (NT) sobre los cambios en la distribución de los diferentes tamaños de poros en suelos con pastoreo directo. Se tomaron muestras a 0-5, 5-10, 10-15 y 15$20 \mathrm{~cm}$ antes y después del pastoreo con bovinos. Se determinó la densidad aparente, la porosidad total y el volumen ocupado por tres tamaños de poros (macroporos, mesoporos y microporos). Las diferencias en la porosidad total entre sistemas de labranza fueron estadísticas $(P<0,01)$ en los $10 \mathrm{~cm}$ superficiales. La menor porosidad total en NT podría reflejar el efecto de los 
años previos de pastoreo. En RT, el laboreo con disco previo a la siembra de la avena (Avena sativa) incrementó la porosidad total en los $10 \mathrm{~cm}$ superficiales y la disminuyó en los 10-20 cm. La macroporosidad representó el 32 (RT) y 20\% (NT) de la porosidad total, disminuyendo al 17 (RT) y 17\% (NT) en profundidad. El pastoreo animal produjo una reducción más importante del espacio poroso en RT que en NT. El laboreo incrementó la macroporosidad, la que fue reducida durante el pastoreo animal. La densidad aparente y la porosidad total fueron adversamente afectadas por debajo de los $15 \mathrm{~cm}$

Palabras clave: porosidad edáfica, compactación animal, región semiárida

J.O. Iglesias: Agronomía, Universidad Nacional del Sur, San Andrés 800, 8000 Bahía Blanca, Argentina. J.A. Galantini: Comisión de Investigaciones Científicas (CIC Pcia. B.A.), CERZOS- Agronomía, UNS, 8000 Bahía Blanca, Argentina. H. Krüger and S. Venanzi: EEA Bordenave-INTA, Ruta Pcial. 76, km 36,5, 8187 Bordenave, Argentina. Correspondence to: jiglesia@criba.edu.ar

\section{INTRODUCTION}

Soil physical properties are critical in the efficient use of the scanty variable rainfall in semiarid regions. Infiltration instead of runoff and retention instead of deep percolation in soil surface layers are processes affecting water availability and hence crop growth, response to fertilizers, nutrient and residue input and, ultimately, the sustainability of the whole system.

Soil porosity, pore size and geometry control water transmission and storage, and provide air and space for root growth (Azooz et al., 1996). Different pore sizes, which fulfill various roles in aeration, infiltration, drainage and storage of water, contribute to total soil porosity. Both soil porosity and pore size distribution integrally affect soil water movement.

Agricultural management modifies pore size distribution as well as pore connectivity. Tillage disrupts pores generated by the biological activity of roots, insects and earthworms, and increases total porosity owing to random fractures.

Conservation tillage systems (no-tillage and reduced-tillage) are effective means of reducing water loss in the soil and improving its moisture regime (Hatfield \& Stewart, 1994). However, tillage effects on soil physical properties are uncertain and variable (Kay \& VandenBygaart, 2002).

Sustainability of mixed systems (agriculture and cattle production) depends heavily on maintaining forage and crop productivity over time. The main factors affecting this productivity are soil chemical fertility and the adverse effect of animal trampling on soil physical properties (Holt et al., 1996; Villamil et al., 1997; da Silva et al., 2003).

Most soil compaction is caused by grazing animals and machinery (Hamza \& Anderson, 2005). Soil compaction due to animal trampling is one of the factors degrading soil physical quality (Imhoff et al., 2000; da Silva et al., 2003). The effect becomes stronger in frequently trampled areas, such as animal trails and resting or drinking places, and in wet soils where water acts as a lubricant helping the intimate packing of mineral particles (Baker \& Davis, 1995; Hamza \& Anderson, 2005). Surface residue cover and root networks can often reduce the mechanical forces protecting the soil from compaction (Greene et al., 1994; Russell et al., 2001). Pietola et al. (2005) found that even low grazing intensities will reduce infiltration and hence increase erosion susceptibility.

Compaction reduces total soil pore space and may increase its shear strength, reduce transmission of water and air through the soil profile, change soil heat capacity, and increase surface runoff and potential erosion (Al Adawi \& Reeder, 1996).

Soil pore volume as well as pore size, shape, type (i.e., biopore vs. crack), continuity, and distribution in soil affects soil water and gas exchange. Vertical drainage and lateral drainage of water by gravitational forces occur through large non-capillary soil pores, but redistribution and upward movement of water occur through capillary soil pores (Amer et al., 2009).

Animal grazing may also directly contribute to higher soil bulk density and reduced pore size and connectivity with the soil surface (Holt et al., 1996). Compaction-induced soil changes may significantly 
Table 1 Monthly temperature and precipitation during the study.

\begin{tabular}{|c|c|c|c|c|c|c|c|c|}
\hline & \multicolumn{4}{|c|}{ Temperature $\left({ }^{\circ} \mathrm{C}\right)$} & \multicolumn{4}{|c|}{ Precipitation (mm) } \\
\hline & 1999 & 2000 & 2001 & 2002 & 1999 & 2000 & 2001 & 2002 \\
\hline January & 21.5 & 23.5 & 21.4 & 21.7 & 153.8 & 46.2 & 126.0 & 13.5 \\
\hline February & 21.2 & 20.3 & 22.5 & 19.3 & 92.2 & 166.2 & 117.0 & 89.0 \\
\hline March & 17.5 & 17.6 & 18.4 & 16.1 & 142.0 & 111.0 & 143.0 & 42.5 \\
\hline April & 12.8 & 14.6 & 13.2 & 11.9 & 77.0 & 20.0 & 118.0 & 50.3 \\
\hline May & 10.1 & 9.9 & 9.4 & 9.3 & 21.6 & 115.2 & 34.5 & 56.5 \\
\hline June & 6.5 & 7.4 & 4.9 & 4.0 & 11.8 & 14.8 & 11.5 & 4.0 \\
\hline July & 6.5 & 4.8 & 6.0 & 5.7 & 18.0 & 9.4 & 15.0 & 34.5 \\
\hline August & 9.0 & 7.5 & 10.0 & 7.6 & 9.6 & 66.6 & 42.0 & 105.8 \\
\hline September & 11.5 & 10.1 & 10.0 & 7.5 & 69.6 & 43.6 & 153.5 & 27.0 \\
\hline October & 14.6 & 13.2 & 14.9 & 10.6 & 51.2 & 131.8 & 174.0 & 91.0 \\
\hline November & 17.7 & 16.3 & 15.4 & 12.6 & 146.2 & 19.8 & 126.8 & 113.0 \\
\hline December & 20.6 & 21.4 & 20.8 & 18.3 & 117.2 & 1.4 & 20.5 & 61.5 \\
\hline
\end{tabular}

reduce root growth (Venanzi et al., 2004). Pabin et al. (1998) reported restricted pea root growth not only in non-irrigated compacted soils but also in irrigated soils or in wet growing seasons due to anoxia, $\mathrm{N}$ loss and root rot infestation, with a subsequent yield reduction.

Some studies have found that the effects of animal grazing were confined to the upper $5 \mathrm{~cm}$ soil layer (Greenwood et al., 1997). However, in wet or recently tilled soils, compaction effects may extend down to $15 \mathrm{~cm}$ (Donkor et al., 2002; Hamza \& Anderson, 2005).

Soils managed under different tillage systems vary in their response to compaction by direct grazing. Their different organic carbon contents and distribution in surface horizons (Galantini et al., 2006; Galantini \& Suñer, 2008) may give rise to differences in the characteristics of their porosity system and in their response to trampling.

Over the last decade, most agricultural activities in Argentina have switched to no tillage (up to $80 \%$ during 2013). However, cattle production was maintained under the traditional tillage systems. This is because animal trampling effects on soil pore space and their impact on water dynamics are still under study.

Information is scanty with regard to the potential changes caused by direct animal grazing in total soil porosity, water storage and transmission properties under different tillage systems, mainly in semiarid environments (Kay \& VandenBygaart, 2002).

We hypothesized that pores naturally produced under NT by biological activity (roots and soil biota) are more resistant to the negative effects of direct grazing than pores produced by tillage.

This study was therefore undertaken with the aim of assessing the effect of direct animal grazing on soil pore space and pore size distribution under reduced and no-till systems.

\section{MATERIALS AND METHODS}

Part of the tillage experiment conducted at Bordenave Experimental Station (National Institute for Agricultural Technology, INTA) was used for this study. The site is located in the south of the semiarid pampas region in Argentina (630.' 20 " $\mathrm{W}$ and $\left.37^{\circ} 51^{\prime} 55^{\prime \prime} \mathrm{S}\right)$. The climate is temperate, continental and semiarid. The mean annual temperature is $15.2^{\circ} \mathrm{C}$ and the average rainfall 670 $\mathrm{mm}$ (1928-2005), with higher precipitation in the fall and the spring. Temperature and precipitation values during the study are shown in Table 1.

The soil, representative of a broad portion of this region, was characterized as a fine, mixed thermic Entic Haplustoll, having a $0-1 \%$ slope and a calcareous layer at a depth between 0.8 and $1 \mathrm{~m}$ from the surface. Table 2 shows some selected soil surface characteristics. The crop sequence of the experiment started with wheat (Triticum aestivum) in 1999, and continued with oat (Avena sativa) in 2000, wheat in 2001, and oat followed by soybean (Glycine max) in 2002.

Table 2. Soil properties of the surface horizon in the experimental site.

\begin{tabular}{lr}
\hline Sand $2.0-0.05 \mathrm{~mm}\left(\mathrm{~g} \mathrm{~g}^{-1}\right)$ & 0.46 \\
Silt $0.05-0.002 \mathrm{~mm}\left(\mathrm{~g} \mathrm{~g}^{-1}\right)$ & 0.35 \\
Clay<0.002 $\mathrm{mm}\left(\mathrm{g} \mathrm{g}^{-1}\right)$ & 0.19 \\
Total organic carbon $\left(\mathrm{g} \mathrm{kg}^{-1}\right)$ & 17.4 \\
Extractable P $\left(\mathrm{g} \mathrm{kg}^{-1}\right)$ & 23.3 \\
$\mathrm{pH}$ (soil:water $1: 2.5)$ & 6.8 \\
\hline
\end{tabular}


The whole trial combined tillage-fertilization treatments, split into grazed and non-grazed areas, with four replicates in a randomized complete block design. Each plot was $4.5 \times 17.5 \mathrm{~m}$. The tillage systems used in the experiment were notill (NT) and reduced-till (RT), which are described in Table 3. In general, RT consisted of up to three tillage trips, the first after harvest (January) and the last before seeding (March to June), and tended to maintain about $30 \%$ of mulch for wind erosion control. Tillage operations were performed up to the 10-15 cm depth using disk grading.

The oat crop was grazed twice in 2000 (April and November) and once in 2002 (June). It was the only forage crop grazed by calves of $260 \mathrm{~kg}$ animal $^{-1}$, at a rate of 300 animals ha- ${ }^{-1}$ for 12 hours.
It is common practice by some farmers to use a high rate for a faster and more uniform harvest of dry matter available for grazing. In this case, it was slightly higher due to the plot size.

Nitrogen fertilizers (30 $\left.\mathrm{kg} \mathrm{N}^{-1}\right)$ were applied only during wheat seeding. The soil sampling was carried out in 2002, before (April 26) and after (July 24) the forage crop was grazed. Surface soil moisture during grazing ranged from 0.20 to $0.22 \mathrm{~g} \mathrm{~g}^{-1}$ (75-80\% of soil water field capacity). Eight undisturbed samples were taken from each treatment, block and soil layer (0-5, 5-10, 10-15 and $15-20 \mathrm{~cm})$ before $(n=256)$ and after $(n=256)$ the grazing period. Cores of $5 \mathrm{~cm}$ in diameter and $5 \mathrm{~cm}$ in height were used. They were saturated under vacuum for $24 \mathrm{~h}$, and subsequently brought

Table 3. Crop and management practices during the study under two tillage systems.

\begin{tabular}{|c|c|c|c|}
\hline Year & Date & \multicolumn{2}{|c|}{ Activity } \\
\hline $1986-1998$ & & \multicolumn{2}{|c|}{ Rotation (3 years Triticum aestivun-3 years Trifolium pratense) } \\
\hline \multirow[t]{2}{*}{1998} & Jun. 6 & & \\
\hline & Nov. 3 & \multicolumn{2}{|c|}{ Millet (Setaria italic) seeding } \\
\hline \multirow[t]{7}{*}{1999} & Apr. 4 & \multicolumn{2}{|c|}{ millet harvest } \\
\hline & & Reduced - till & No - till \\
\hline & Jun. 7 & & Glyphosate+2,4-D \\
\hline & Jun. 15 & \multicolumn{2}{|l|}{ Disk harrow at 10 to $15 \mathrm{~cm}$} \\
\hline & Jun. 17 & \multicolumn{2}{|c|}{ Wheat seeding } \\
\hline & Aug. 26 & \multicolumn{2}{|c|}{ Weed control } \\
\hline & Sept. 15 & \multicolumn{2}{|c|}{ Weed control } \\
\hline \multirow[t]{6}{*}{2000} & Jan. 11 & \multicolumn{2}{|c|}{ Wheat harvest } \\
\hline & Jan. 12 & Disk harrow (fallow) & Glyphosate + 2,4-D (fallow) \\
\hline & Feb. 15 & Disk harrow & Glyphosate+2,4-D \\
\hline & Mar. 23 & \multicolumn{2}{|c|}{ Oat seeding } \\
\hline & Apr. 25 & \multicolumn{2}{|c|}{ 1st. grazing 200 animals ha-1 } \\
\hline & Nov. 6 & \multicolumn{2}{|c|}{ 2nd.grazing 200 animals ha ${ }^{-1}$} \\
\hline \multirow[t]{8}{*}{2001} & Feb. 14 & Disk harrow (fallow) & Glyphosate+2,4-D (fallow) \\
\hline & Mar. 27 & Disk harrow & Glyphosate \\
\hline & Jun. 22 & & Wheat seeding $\left(+40 \mathrm{~kg} \mathrm{~N} \mathrm{ha}^{-1}\right)$ \\
\hline & Jun. 25 & \multicolumn{2}{|c|}{ Wheat seeding $\left(+40 \mathrm{~kg} \mathrm{~N} \mathrm{ha}^{-1}\right)$} \\
\hline & Jun. 29 & \multicolumn{2}{|c|}{ Paraquat } \\
\hline & Aug. 17 & \multicolumn{2}{|c|}{ Clodinafop-propargyl } \\
\hline & Sept. 4 & \multicolumn{2}{|c|}{ Mutsulfuron } \\
\hline & Dec. 21 & \multicolumn{2}{|c|}{ Wheat harvest } \\
\hline \multirow[t]{9}{*}{2002} & Jan. 11 & Disk harrow (fallow) & Glyphosate + 2,4-D (fallow) \\
\hline & Feb. 6 & & Glyphosate+2,4-D \\
\hline & Feb. 27 & Disk harrow & \\
\hline & Feb. 28 & \multicolumn{2}{|c|}{$\begin{array}{l}\text { Oat seeding + STP } 20 \mathrm{~kg} \mathrm{ha}^{-1} \\
\text { Soil sampling }\end{array}$} \\
\hline & Apr. 26 & \multicolumn{2}{|c|}{ Soil sampling } \\
\hline & May. 31 & \multicolumn{2}{|c|}{ grazing 300 animals ha ${ }^{-1}$} \\
\hline & Jul. 24 & \multirow{2}{*}{\multicolumn{2}{|c|}{ Soil sampling }} \\
\hline & Jul. 9 & & \\
\hline & Sept. 30 & & Glyphosate + 2,4 D \\
\hline
\end{tabular}


to $0,-10,-33,-100$ and $-1500 \mathrm{kPa}$ using a pressureplate apparatus (Richards, 1947; Klute \& Dirksen, 1986). Soil water content was determined at each equilibrium water potential and it was expressed on a volumetric basis using bulk densities of individual cores.

Bulk density and total porosity (Blake \& Hartge, 1986) were determined and pore size distribution was calculated. Three pore size classes were considered using an approach based on their functional differences related to water movement and storage capacity (Iglesias et al., 1996; Kay \& VandenBygaart, 2002): a) macropores (MP, > $9 \mu \mathrm{m}$ diameter), which control soil aeration and allow primary water flux during infiltration and drainage; b) mesopores (mP, 9 - $0.2 \mu$ m diameter), whose extreme values correspond to field capacity and permanent wilting point, and are especially important to water storage; and $c)$ micropores ( $\mu \mathrm{P}$, $<0.2 \mu \mathrm{m}$ diameter), which were assumed to hold water unavailable to plants. Macropores were divided into big $(>30 \mu \mathrm{m})$ and small $(30-9 \mu \mathrm{m})$, and mesopores were divided into big (9-3 $\mu \mathrm{m})$ and small $(3-0.2 \mu \mathrm{m})$ in terms of their accessibility to microorganisms. The effective pore neck diameter (d) was estimated in each undisturbed soil sample from the water retention curve as:

$$
\mathrm{d}=2 \mathrm{r}=-30.0 \times 10^{-6} \mathrm{~h}^{-1}(\mathrm{~m})
$$

where $h$ is pressure head, $r$ is the radius of curvature of the capillary pore (m) (Hassink et al., 1993).

Plant-available water capacity (AWC) was calculated as the difference between soil water retained at $-33 \mathrm{kPa}$ and $-1500 \mathrm{kPa}$.

Analysis of variance for each soil depth was carried out with InfoStat software (Di Rienzo et al., 2011), using a randomized complete block design with four replications. The tillage effect was analyzed before and after the grazing period, and the trampling effect was evaluated in each tillage system.

\section{RESULTS AND DISCUSSION}

\section{Total porosity}

After oat planting and before grazing, total porosity was about $50 \%$ in both tillage systems, this value allowing the normal root development (Venanzi et al., 2004). Total porosity values were 53 and $58 \%$ in the surface layer under NT and $\mathrm{RT}$, respectively, decreasing with soil depth in both treatments (Figure 1a). Differences in total porosity between tillage systems were statistically significant $(P<0.01)$ in the top $10 \mathrm{~cm}$ layer.

Lower total porosity under NT could be related to the effect of two prior grazing periods during the oat crop and to the short time elapsed since the commencement of the no-till management (3 years). Total porosity is often lower under NT than under RT (Kay \& VandenBygaart, 2002). The results over more than 15 years have been consistent in showing lower total porosity under NT in the 5-20 $\mathrm{cm}$ depth, but frequently higher in the $0-5 \mathrm{~cm}$ layer. This is usually associated with a build-up of organic matter content at this depth and the related biological activity, as determined in other studies performed in these plots (Galantini et al., 2002; 2004; Duval et al., 2013).

Under RT, two disk operations before planting the oat crop probably increased total porosity values in the tilled zone $(0-10 \mathrm{~cm})$ and decreased them in the $10-20 \mathrm{~cm}$ layer.

After grazing, treatment differences in total

\section{Tillage effects}

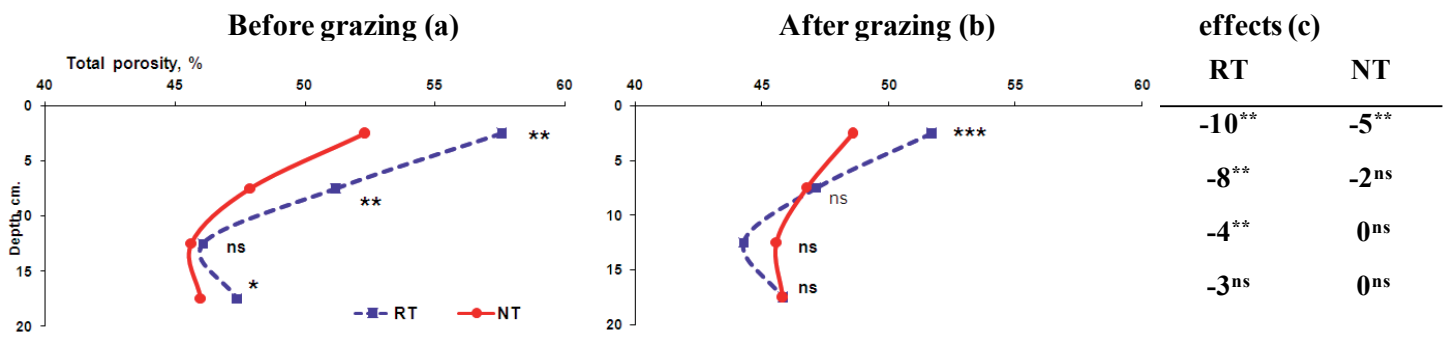

ns, not significant; ${ }^{*},{ }^{* *},{ }^{* * *}$ significant at the $0.05,0.01$ and 0.001 probability levels, respectively. Trampling effect $(\%)=100^{*}($ Initial value - final value)/Initial value.

Figure 1 Total porosity values along soil depth before (a) and after (b) grazing under reduced (RT) and no-till (NT) systems, and trampling effects (c). 
porosity were concentrated in the top $5 \mathrm{~cm}$, with higher values for RT (Figure 1b). However, cattle trampling reduced total soil porosity in both tillage treatments. In NT, the cattle trampling effect was limited to the top $5 \mathrm{~cm}$ and it was significantly low (5\% of the initial value). In RT, however, the effect reached deeper layers and it was more pronounced. Reduction in total soil porosity affected the $15 \mathrm{~cm}$ depth and represented 10, 8.5 and $4 \%$ of the initial value for the $0-5,5-10$, and $10-15 \mathrm{~cm}$ layers, respectively (Figure 1). These results are in line with Pietola (2005), who found severe trampling effects only in the $0-5 \mathrm{~cm}$ layer of a sandy loam soil under pasture (to some extent comparable to NT). In their review dealing mainly with conventional tillage systems, Hamza and Anderson (2005) also found soil compaction effects due to animal trampling to a depth of $20 \mathrm{~cm}$, the top $5 \mathrm{~cm}$ showing the greatest impact.

Since soil water content at grazing was similar for both treatments, the higher soil cover, mulch, and mechanical impedance observed in surface layers under NT (data not shown) may have protected deeper layers from compaction. Mechanical impedance increased load support capacity of the soil, thereby reducing compaction depth (Hamza \& Anderson, 2005). The more pronounced change observed in RT also reveals the lower resistance of tillage-induced porosity. As a final result of grazing, the most important differences in total porosity between treatments were observed in the topsoil $(0-5 \mathrm{~cm})$ layer.

\section{Pore size distribution}

Distribution of large and small macropores along depth for both studied treatments, before and after grazing, are shown in Figure 2. Before grazing, total macropores (big macropores + small macropores) accounted for 32 (RT) and $20 \%$ (NT) of total porosity in the soil surface, decreasing with depth to 17 (RT) and $17 \%$ (NT).

Big macropores accounted for most of the macroporosity in the $0-20 \mathrm{~cm}$ layer. A significant management effect was observed in the big macropore volume of the upper layer owing to surface tillage prior to sowing under RT.

Small macropores were less abundant than large ones, the amount varying with depth and between tillage systems.

Animal trampling reduced macropore volume in both treatments. For big macropores, the effect was noted only in the 0-5 cm layer under NT, whereas it extended from the surface to $15 \mathrm{~cm}$ under RT. The trampling effect was higher on tillage-induced porosity under RT (Figure 2c). Big macropores

\section{Tillage effects}

\section{Before grazing (a)}

After grazing (b)

\section{Trampling \\ effects (c)}
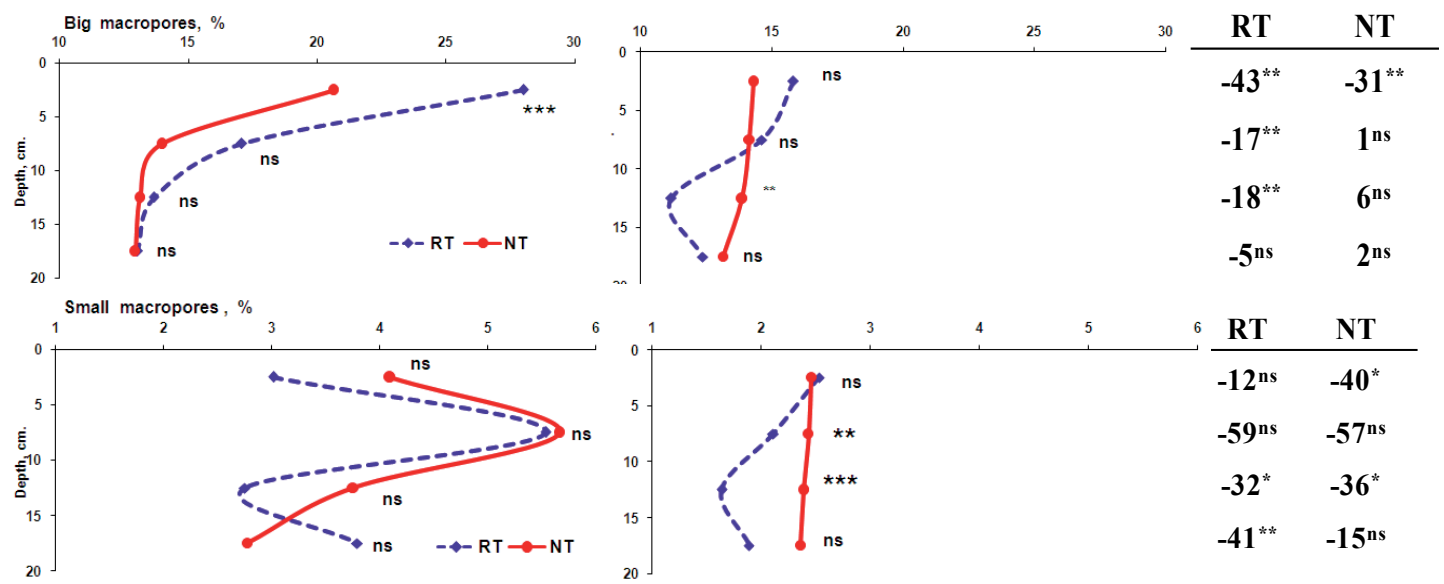

\begin{tabular}{ll} 
RT & NT \\
\hline$-12^{\text {ns }}$ & $-40^{*}$ \\
$-59^{\text {ns }}$ & $-57^{\text {ns }}$ \\
$-32^{*}$ & $-36^{*}$ \\
$-41^{* *}$ & $-15^{\text {ns }}$
\end{tabular}

ns, not significant; ${ }^{* * *},{ }^{* * *}$ significant at the $0.05,0.01$ and 0.001 probability levels, respectively. Trampling effect $(\%)=100 *($ Initial value - final value)/Initial value.

Figure 2. Distribution of big and small macropores along soil depth before and after grazing in reduced (RT) and no-till (NT) systems, and trampling effects (c). 
were significantly reduced at the 0-5 (-43\%), 5-10 $(-17 \%)$ and $10-15(-18 \%)$ cm layer under RT, while under NT the reduction was only observed at the $0-5(-31 \%) \mathrm{cm}$ layer.

Small macropores decreased in both treatments and at all depths studied. Although the relative decrease was significant, especially within the 5-20 $\mathrm{cm}$ layer under RT and 0-15 cm layer under NT, the absolute changes in magnitude were actually low (owing to the low initial values) (Figure 2e).

At the 5-15 cm depth, a compacted layer began to differentiate in RT, with a decrease in the amount of macropores (big and small) with respect to NT. Though often attributed to the impact of machinery alone, changes occurring in this layer result, in fact, from the combined effect of disk tillage (usually at 10-12 cm depths) and animal trampling.

Although the magnitude of the relative change in porosity as a result of trampling was higher in other pore classes, the larger volume of macropores implies that they accounted for most of the variation. Total porosity changes were mostly attributable to alterations in big macropores, which were also responsible for the differences between treatments. As in the case of total porosity, such differences were concentrated mainly in the topsoil $(0-5 \mathrm{~cm})$ before grazing and in the $10-15 \mathrm{~cm}$ after grazing. Deformation of big and small macropores increased mesopore and micropore values. When soils are converted to no-till management, variations in macroporosity in both space and time can be expected to be much greater than in the case of smaller pores (Kay \& VandenBygaart, 2002; Berisso et al., 2013).

The effects of trampling on macroporosity were higher than the results obtained by Mapfumo et al. (2000). The effect found by these authors after 3 years of grazing with heavy, medium, and light intensities in a Typic Haplustoll may have been due to resilient intrinsic properties of the soil and the short duration of their study. In our case, the results could also be explained by the high intensity of grazing and the low limit used for classification as a macropore $(30 \mu \mathrm{m})$. The larger pores are more susceptible to changes owing to tillage and other soil disturbances.

Grazing had a positive effect on mesopore content owing to the decrease of the macropores which were transformed to meso or micropores. Under RT, big and small mesopores were significantly increased at $10-15 \mathrm{~cm}(23 \%)$ and $0-5 \mathrm{~cm}(35 \%)$, respectively. Under NT, however, the increase in these pore sizes occurred at $0-15 \mathrm{~cm}$ (from 21 to $38 \%$ ) and $0-10 \mathrm{~cm}$ (from 12 to 20\%). Big mesopore values were higher under RT than under NT in the upper 0-5 cm layer, whereas no differences were found at lower depths or in small mesopores (Figure 3a). After grazing, the volume of big mesopores in the $5-10 \mathrm{~cm}$ layer was higher under NT than under RT. Small mesopores in the upper layer were more abundant under RT as compared with NT, whereas in the deeper layer they were higher in number under NT with respect to RT. Micropores ranged from 25-30\% of total pore space in the surface to $40 \%$ in deeper layers. Under RT, the tramping effect increased micropores in the 0-5 and $5-10 \mathrm{~cm}$ depths. The amount of micropores in the 0-5 layer was lower under RT as compared with NT. There were no differences at greater depths. After grazing, micropores tended to increase in the surface layer under NT and in all layers under $\mathrm{RT}$, probably due to the strong correlation between soil structure and C and microbial activity and C (Cui \& Holden, 2015). Significant differences were observed at the 10-15 depth. Here, a compacted layer began to differentiate under RT, with a decrease in macropores and an increase in the proportion of micropores with respect to NT.

\section{Bulk density and available water capacity}

Bulk density before grazing was statistically lower in the upper 0-5 and 5-10 cm layers under RT than under NT (Table 4). After grazing, bulk density was higher in the 0-5 cm layer under NT with respect to RT. The grazing effect on bulk density was higher under RT, at the 0-5 (+20\%), 5-10 (+8\%) and 10-15 $(+5 \%) \mathrm{cm}$ depths, while under NT the effect was observed only at the $0-5(+11 \%) \mathrm{cm}$ depth.

Changes in bulk density and pore distribution significantly affected water storage capacity in the topsoil $5 \mathrm{~cm}$ layer under RT, without a significant change in the available water capacity for the $0-20 \mathrm{~cm}$ layer. The grazing effect under NT was deeper, and reached 0-5 and 5-10 cm; however, the available water capacity in the $0-20 \mathrm{~cm}$ layer did not increase much, with values ranging from 22.4 to $24.9 \mathrm{~mm}$. Other studies have found similar responses (Bilotta et al., 2007), most likely because reduction of storage pores is compensated by bigger pores which reduce their size.

\section{CONCLUSIONS}

Animal trampling reduced total soil porosity in both tillage systems. The effect was concentrated in the 0-5 cm layer under NT and reached the 10$15 \mathrm{~cm}$ layer under RT, where a compacted layer develops. A combination of big macropores and 


\section{Tillage effects}

Before grazing (a)
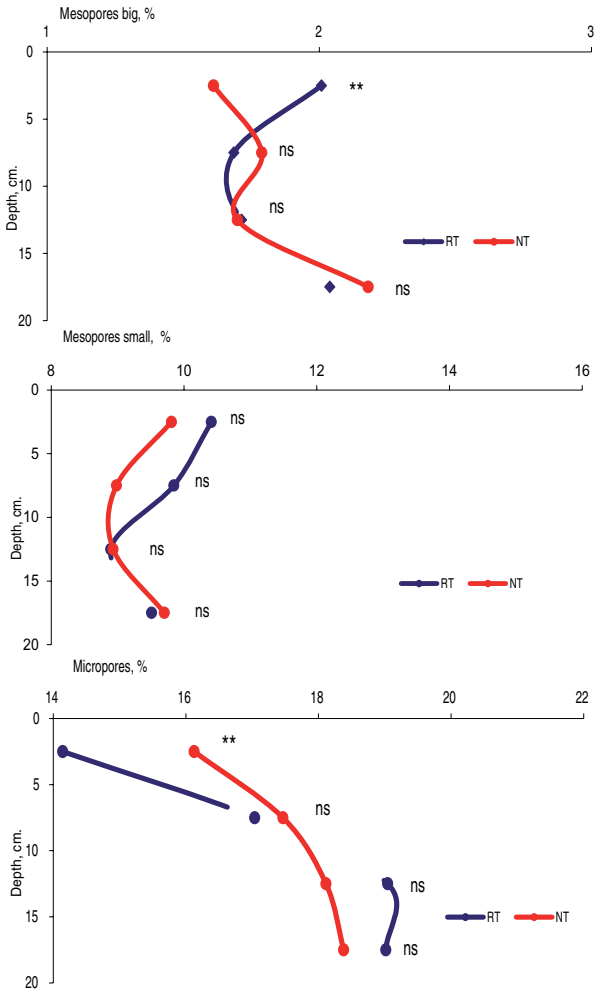

\section{Tramping}

effects (c)

After grazing (b)

${ }_{3}$ RT NT
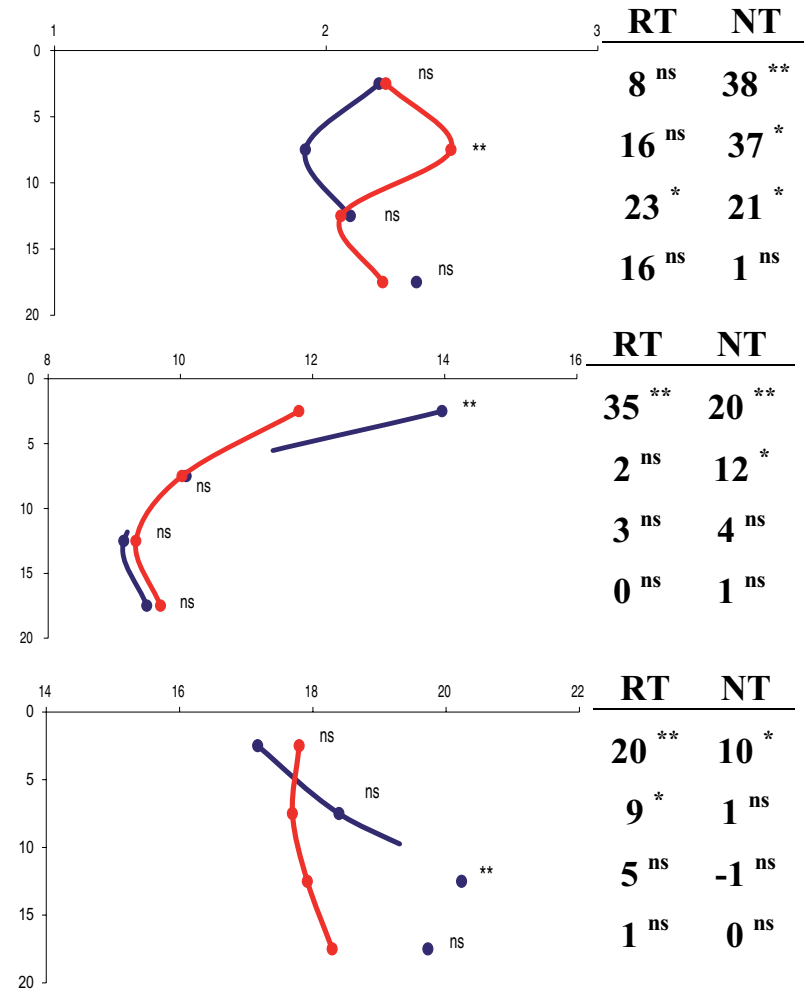

ns, not significant; ${ }^{* * *},{ }^{* * *}$ significant at the $0.05,0.01$ and 0.001 probability levels, respectively. Trampling effect $(\%)=100 *($ Initial value - final value)/Initial value

Figure 3. Distribution of mesopores (big and small) and micropores along soil depth before and after grazing in reduced (RT) and no-till (NT) systems, and trampling effects (c).

Table 4. Bulk density and available water capacity under reduced (RT) and no-till (NT) systems, before (a) and after (b) animal grazing, and trampling effects (c).

\begin{tabular}{|c|c|c|c|c|c|c|}
\hline \multicolumn{5}{|c|}{ Tillage effects } & \multirow{2}{*}{\multicolumn{2}{|c|}{$\begin{array}{l}\text { Trampling } \\
\text { effects (c) }\end{array}$}} \\
\hline \multirow{3}{*}{$\begin{array}{l}\text { Depth } \\
(\mathrm{cm})\end{array}$} & \multicolumn{2}{|c|}{ Before $(\mathrm{a})$} & \multicolumn{2}{|c|}{ After (b) } & & \\
\hline & RT & NT & RT & NT & RT & NT \\
\hline & \multicolumn{4}{|c|}{ Bulk density $\left(\mathrm{Mg} \mathrm{m}^{-3}\right)$} & \multicolumn{2}{|c|}{$\%$} \\
\hline $0-5$ & 1.08 & $1.21^{* * *}$ & 1.29 & $1.34^{* *}$ & $20^{* *}$ & $11^{*}$ \\
\hline $5-10$ & 1.28 & $1.38^{* *}$ & 1.39 & $1.40^{\text {ns }}$ & $5^{*}$ & $1^{\text {ns }}$ \\
\hline $10-15$ & 1.39 & $1.40^{\text {ns }}$ & 1.45 & $1.39^{\text {ns }}$ & $5^{*}$ & $-1^{\text {ns }}$ \\
\hline $15-20$ & 1.35 & $1.37^{\mathrm{ns}}$ & 1.37 & $1.37^{\mathrm{ns}}$ & $1^{\mathrm{ns}}$ & $0^{\text {ns }}$ \\
\hline \multirow[t]{2}{*}{$0-20$} & 1.28 & 1.34 & 1.38 & 1.38 & & \\
\hline & \multicolumn{4}{|c|}{ Available water capacity (mm) } & \multicolumn{2}{|c|}{$\%$} \\
\hline $0-5$ & 6.21 & $5.71^{\mathrm{ns}}$ & 8.09 & $7.01^{* *}$ & $30^{* *}$ & $23^{* *}$ \\
\hline $5-10$ & 5.77 & $5.39^{\text {ns }}$ & 5.96 & $6.24^{\mathrm{ns}}$ & $4^{\text {ns }}$ & $16^{*}$ \\
\hline $10-15$ & 5.31 & $5.32^{\mathrm{ns}}$ & 5.62 & $5.69^{\text {ns }}$ & $6^{\text {ns }}$ & $7^{\mathrm{ns}}$ \\
\hline $15-20$ & 5.78 & $5.94^{\mathrm{ns}}$ & 5.94 & $6.00^{\text {ns }}$ & $3^{\text {ns }}$ & $1^{\mathrm{ns}}$ \\
\hline $0-20$ & 23.1 & 22.4 & 25.6 & 24.9 & & \\
\hline
\end{tabular}

ns, not significant; ${ }^{*}{ }^{* *},{ }^{* * *}$ significant at the $0.05,0.01$ and 0.001 probability levels, respectively. Trampling effect $(\%)=100^{*}($ Initial value - final value)/Initial value 
small mesopores accounted for the difference. Macroporosity was lower under RT in the $10-15 \mathrm{~cm}$ layer. The most important differences occurred in tilled soils, suggesting its macropore instability.

These results indicate that $R T$ is fairly susceptible to the negative effects of animal trampling, since its porous system is more dependent on periodic till. In NT, however, such effects are less pronounced, which make it more suitable for these semiarid environments.

\section{ACKNOWLEDGMENTS}

The authors thank Paula Motter for cooperating in the translation of this paper.

\section{REFERENCES}

Al Adawi, S.S. and R.C. Reeder, 1996. Compaction and subsoiling effects on corn and soybean yields and soil physical properties. Trans. of the ASAE. 39: 16411649.

Amer, AM. M.; S.D. Logsdon and D. Dedrick, 2009. Prediction of Hydraulic Conductivity as Related to Pore Size Distribution in Unsaturated Soils. Soil Science 174(9): 508-515.

Azooz, R.H.; M.A. Arshad and A.J. Franzluebbers, 1996. Pore size distribution and hydraulic conductivity affected by tillage in Northwestern Canada. Soil Science Society America Journal 60: 1197-1201.

Baker, D.M. and R.J. Davis, 1995. Soil deformation observations in a Vertisol under field traffic. Australian Journal Soil Research 33: 817-832.

Berisso, F.E.; P. Schjønning, T. Keller, M. Lamandé, A. Simojoki, B.V. Iversen, L. Alakukku and J. Forkman, 2013. Gas transport and subsoil pore characteristics: Anisotropy and long-term effects of compaction. Geoderma 195-196: 184- 191.

Bilotta, G.S.; R. E. Brazier and P.M. Haygarth, 2007. The impacts of grazing animals on the quality of soils, vegetation and surface waters in intensively managed grasslands. Advances in Agronomy 94: 237-280.

Blake, G.R. and K. H. Hartge, 1986. Bulk density. In: Klute A. (Ed.) Methods of soil analysis. Part 1. $2^{\text {nd }}$ ed. Agron. Monogr. 9 ASA and SSSA, Madison, WI. pp 363-375.

Cui, J. and N.M. Holden, 2015. The relationship between soil microbial activity and microbial biomass, soil structure and grassland management. Soil and Tillage Research 146A: 32-38.

da Silva, A.P.; S. Imhoff and M. Corsi, 2003. Evaluation of soil compaction in an irrigated short-duration grazing system. Soil and Tillage Research 70: 83-90.
Di Rienzo, J.A.; F. Casanoves, M.G. Balzarini, L. Gonzalez, M. Tablada y C.W. Robledo, 2011. InfoStat. Grupo InfoStat. FCA, Universidad Nacional de Córdoba, Argentina.

Donkor, N.T.; J.V. Gedir, R.J. Hudson, E.W. Bork, D.S. Chanasyk and M.A Naeth, 2002. Impacts of grazing systems on soil compaction and pasture production in Alberta. Canadian Journal Soil Science 82: 1-8.

Duval, M.; J.A. Galantini, J.O. Iglesias y H. Krüger, 2013. El cultivo de trigo en la región semiárida bonaerense: Impacto sobre algunas propiedades químicas del suelo. RIA - INTA 39(2): 178-184.

Galantini, J.A.; R.A. Rosell, G. Brunetti y N. Senesi, 2002. Dinámica y calidad de las fracciones orgánicas de un Haplustol durante la rotación trigo-leguminosas. Ciencia del Suelo 20: 17-26.

Galantini, J.A.; N. Senesi, G. Brunetti and R. Rosell, 2004. Influence of texture on the nitrogen and sulphur status and organic matter quality and distribution in semiarid Pampean grassland soils. Geoderma 123: 143-152.

Galantini, J.A.; J.O. Iglesias, C. Maneiro, L. Santiago y C. Kleine, 2006. Sistemas de labranza en el sudoeste bonaerense. Efectos de largo plazo sobre las fracciones orgánicas y el espacio poroso del suelo. Revista de Investigaciones Agropecuarias (RIA) INTA 35: 15-30.

Galantini, J.A. y L. Suñer, 2008. Las fracciones orgánicas del suelo: Análisis en los suelos de la Argentina. Revisión. AgriScientia XXV(1) : 41-55.

Greene, R.; P. Kinnell and J.T. Wood, 1994. Role of plant cover and stock trampling on runoff and soil erosion from semiarid wooded rangelands. Australian Journal Soil Research 32: 953-973.

Greenwood, K.L.; M.A. MacLeod and K.J. Hutchinson, 1997. Long-term stocking rate effects on soil physical properties. Australian Journal of Experimental Agriculture 37: 413-419.

Hamza, M.A. and W.K. Anderson, 2005. Soil compaction in cropping systems. A review of the nature, causes and possible solutions. Soil and Tillage Research 82: 121-145.

Hassink, J.; L.A.Bouwman, K.B. Zwart, J. Bloem and L. Brussaard, 1993. Relationships between soil texture, physical protection of organic matter, soil biota, and $\mathrm{C}$ and $\mathrm{N}$ mineralization in grassland soils. Geoderma 57: 105-128.

Hatfield, J.L. and B. A. Stewart, 1994. Soil biology effects on soil quality. Advances in Soil Science. Ann Arbor, MI: Lewis Publishers. 169 pp.

Holt, J.A.; K. L. Bristow and J.G. Mclvor, 1996. The effects of grazing pressure on soil animals and hydraulic properties of two soils in semi-arid tropical Queensland. Australian Journal Soil Research 34: 69-79. 
Iglesias, J.O.; J. Galantini, R. Rosell, A. Miglierina y M. Landriscini, 1996. Cambios en la distribución del espacio poroso de un Entic Haplustoll con diferentes secuencias de cultivos de la región semiárida de Argentina. Agricultura Técnica 56: 43-48.

Imhoff, S.; A.P. Silva and C.A. Tormena, 2000. Applications of the resistance curve in the control of the physical quality of soils under grass. Pesquisa Agropecuaria Brasileira 35: 1493-1500.

Kay, B.D. and A.J. VandenBygaart, 2002. Conservation tillage and depth stratification of porosity and soil organic matter. Soil and Tillage Research 66: 107-118.

Klute, A. and C. Dirksen, 1986. Water retention: Laboratory Methods. In: Klute, A. (Ed.) Methods of soil analysis. Part 1. Physical and Mineralogical Methods ASA SSSA Madison WI, pp. 635-662.

Mapfumo, E.; D.S. Chanasyk, V.S. Baron and M.A. Naeth, 2000. Grazing impacts on selected soil parameters under short-term forage sequences. Journal of Range Management 53: 466-470.

Pabin, J.; J. Lipiec, S. Wlodek, A. Biskupsky and A. Kaus, 1998. Critical soil bulk density and strength for pea root growth as related to other soil factors. Soil and
Tillage Research 43: 206-208.

Pietola, L., 2005. Root growth dynamics of spring cereals with discontinuation of mouldboard ploughing. Soil and Tillage Research 80: 103-114.

Pietola, L.; R. Horn and M. Yli-Halla, 2005. Effects of trampling by cattle on the hydraulic and mechanical properties of soil. Soil and Tillage Research 82: 99108.

Richards, L.A., 1947. Pressure-membrane apparatus. Construction and use. Agricultural Engineering 28: 451-454.

Russell, J. R.; K. Betteridge, D.A. Costall and A.D. Mackay, 2001. Cattle treading effects on sediment loss and water infiltration. Journal of Range Management 54: 184-190.

Venanzi, S.; H. Krüger y J.A. Galantini, 2004. Pastoreo en siembra directa y crecimiento de soja. XIX Congreso Argentino de la Ciencia del Suelo (en CD).

Villamil, M.B.; N.M. Amioti y N. Peinemann N, 1997. Pérdida de fertilidad física en suelos del sur del Caldenal (Argentina) por sobrepastoreo. Ciencia del Suelo 15: 102-104. 